THE C U L T R E AND COMMERCE

OF PUBLISH ING

IN THE 21ST CENTURY 



\title{
THE CULTURE
}

\section{AND COMMERCE}

\section{OF PUBLISHING}

\section{IN THE 21ST CENTURY}

\author{
ALBERT N. GRECO, \\ CLARA E. RODRíGUEZ, \\ AND ROBERT M. WHARTON
}

ST A N F ORD BUSINESS B OOKS

An Imprint of Stanford University Press

Stanford, California 2007 
Stanford University Press

Stanford, California

CO2007 by the Board of Trustees of the Leland Stanford Junior University. All rights reserved.

No part of this book may be reproduced or transmitted in any form or by any means, electronic or mechanical, including photocopying and recording, or in any information storage or retrieval system without the prior written permission of Stanford University Press.

Printed in the United States of America on acid-free, archival-quality paper

Library of Congress Cataloging-in-Publication Data

Greco, Albert N., 1945-

The culture and commerce of publishing in the 21st century / Albert N. Greco, Clara E. Rodriguez, and Robert M. Wharton.

p. $\mathrm{cm}$.

Includes bibliographical references and index.

ISBN-13: 978-0-8047-5031-8 (alk. paper)

1. Publishers and publishing-United States. I. Rodriguez, Clara E., 1944- II. Wharton, Robert M. III. Title.
Z471.G743 2007

070.50973 - dc22

2006019876

Typeset by G \& S Book Services in 10/13.5 Minion

Special discounts for bulk quantities of Stanford Business Books are available to corporations, professional associations, and other organizations. For details and discount information, contact the special sales department of Stanford University Press. Tel: (650) 736-1783, Fax: (650) 736-1784 